to be the better explanation because in any given group of eggs containing both fertiljzed and un fertilized ova it was possible to observe many unfertilized eggs in which spermatozoa had penetrated deeply into the zona pellucida but had not reached the perivitelline space.

We thank Dr. T. Mann for his encouragement and criticism.

R. W. NOYES

A. WAITON

C. F. Adams

Agricultural Research Council

Unit of Reproductive Physiology and Biochemistry,

University of Cambridge.

'Chang, M. C., Nature, 168, 697 (1951).

Austin, C. R., Austral. J. Sci., Res. B, 4, 581 (1951).

${ }^{s}$ Chang, M. C., Nature, 175, 1036 (1955).

-Austin, C. R., Nature, 170, 326 (1952)

Austin, C. R., and Braden, A. W. H., Austral. J. Biol. Sci., 7, 179 (1954).

- Noyes, R. W., West. J. Surg. Obstet. and Gynec., 61, 342 (1953).

\section{Ovulation induced in Frog with Mammalian Hormones}

We have reported elsewhere ${ }^{1}$ that fertilizable eggs for embryological studies can be obtained satisfactorily from the ubiquitous Indian skipper-frog (Rana cyanophlyctis Schn.). Homoplastic parenteral injections of 4-5 pituitary glands into gravid test animals brought forth viable eggs after 12-15 hr. It was our object to find out if mammalian hormones could also induce these frogs to ovulate, as there is conflicting opinion about the action of gonadotrophins on female frogs. Rugh ${ }^{2}$ noted in this connexion that "In general, the Anura will respond to pituitaries from other Amphibia but not from mammalian extracts of the pituitary hormone". However, Creaser and Gorbman ${ }^{3}$ quoted authors reporting ovulation in two species of Rana induced by mammalian hormones. Whereas many workers have reported failure to induce Rana pipiens to ovulate with mammalian gonadotrophins, Wright and Hisaw appear to have succeeded with mammalian pituitary gonadotrophins. Ovulation has been brought about in frogs using testosterone, progesterone and adrens. cortical hormones, 5 . Chang and Witschi ${ }^{7}$ suggested that cortisone and adrenocorticotrophic hormone play a supporting part in the process of ovulation in R. pipiens and that the ovary should be brought to a threshold by implanting one or two pituitary glands to enable the supporting agent to work. It has been assumed in explaining this action that the process of ovulation is caused by the high follicular cestrogen content, which in turn releases adrenocorticotrophic hormone from the pituitary, the latter activating the adrenal cortex to secrete cortisone which assists in ovulation.

We have been using an array of mammalian hormones to study the reaction of local frogs. The breeding season of these frogs coincides with the onset of monsoon showers (June-September) and we have not noticed any winter breeding in the skipperfrog. Our experiments started in September 1957 and are being continued. It was found that a parenteral injection of two gravid pituitary glands of the skipper-frog homogenized in distilled water is not normally capable of making these gravid frogs spawn or yield viable eggs on stripping; they require four or more glands as stated above. But two glands, when injected with $0.625 \mathrm{mgm}$. of cortisone acetate (Glaxo), made 70 per cent of the test animals spawn and yiold viable eggs on stripping within $20 \mathrm{hr}$.; with only one gland, it takes longer for the frogs to yield eggs. Similar experiments using combinations of two glands with adrenocorticotrophic hormone (Dumex), serum gonadotrophin ('Antex': Dumex), chorionic gonadotrophin ('Physex': Dumex; 'Antuitrin $S^{\prime}$ : Parke Davis), follicle-stimulating hormone (Armour), luteinizing hormone (Armour), progesterone ('Luteostab': Boots), methyltestosterone (Boots), growth hormone ('Somar': Armour) and thyroidstimulating hormone (Armour) respectively have been tried on the skipper-frog. The frogs spawned within 20-22 hr. after receiving these hormones in combination; those receiving particularly 'Antuitrin S', luteinizing and growth hormones in combination spawned profusely. The eggs hatched out into tad. polos after fertilization. Apart from controls injected with progesterone and testosterone, other frogs receiving equal quantitios of the other mammalian hormones did not spawn or yield viable eggs on stripping. It is extraordinary that frogs which do not normally ovulate and spawn with mammalian gonedotrophins should have reacted when growth and thyroid-stimulating hormones were used in combination with pituitary glands of the same species; these hormones are not known to be ovulating sgents and this is probably the first report of these two hormones functioning as augmenting agents. That the growth hormone does not contain any ovulating factor was ascertained: it does not produce any ovulation in the skipper-frog when used in association with trypsin-digested frog pituitary gland in which the $L H$-factor has been destroyed or inactivated.

Three important results emerge from these bioassays. First, we are able to confirm the observation of $\mathrm{Rugh}^{2}$, since our frogs also are refractory to mammalian gonadotrophins, differing thereby from those of Wright and Hisaw ${ }^{4}$. Fertilizable eggs can thus be obtained by homoplastic pituitary injections or by the use of synergic agents such as cortisone or growth hormone. Secondly, while it may be true that adrenocorticotrophic hormone and cortisone function in the chain reaction, as assumed by Chang and Witschi? the tests conducted by us lead us to infer that hormones unconnected with ovulation may also act as augmenting agents. Thirdly, androgen and progesterone can bring about ovulation in our frogs and can also act as augmenting agents. Details of these experiments will be published elsewhere.

We thank Prof. B. R. Seshachar for continued encouragement, Dr. Irby Bunding (Armour, Chicago) for generous help with mammalian hormones, and one of us (A. B. L.) is indebted to the Council of Scientific and Industrial Research, New Delhi, for the award of a scholarship.

Department of Zoology, Central College,

Bangalore. Feb. 15.

${ }^{2}$ Ramaswami, I. S., and Lakshman, A. B. (in the press).

"Rngh, R., "Experimental Embryology" (Burgess, Minneapolis, 1948).

${ }^{s}$ Creaser, C. W., and Gorbman, A., Quart. Rev. Biol., 14, 311 (1939).

"Wright, P. A., and Hisaw, F, L., Endocrinol., 39, 247 (1946).

${ }^{5}$ Langan, W. B., Proc. Soc. Exp. Biol. and Med., 47, 59 (1941).

- Shapiro, H. A., Chem. and Indust., 55, 1031 (1936).

${ }^{7}$ Chang, C., and Witschi, E., Endocrinol., 61, 514 (1957). 